\title{
Molecular and serological detection of Babesia Bovis and Babesia Bigemina in cattle in the Rio de Janeiro, Brazil
}

\author{
Detecção molecular e sorológica de Babesia Bovis e Babesia \\ Bigemina em bovinos no Rio de Janeiro, Brasil
}

\author{
Jenevaldo Barbosa da Silva ${ }^{1 *}$; Priscilla Nunes dos Santos ${ }^{2}$; \\ Adivaldo Henrique Fonseca ${ }^{3}$
}

\begin{abstract}
Bovine babesiosis is an important disease of cattle where Rhipicephalus microplus acts as a vector for the two causal organisms Babesia bovis and Babesia bigemina. A total of 22 calves were randomly monitored during three years by semi-nested PCR assay and ELISA test to determine prevalence of $B$. bovis and B. bigemina. The overall prevalence of B. bovis and B. bigemina was $30 \%$ and $35 \%$ by nested PCR ( $n$ PCR), and $70 \%$ and $75 \%$ by ELISA, respectively. Statistical analysis of the characteristics of animals showed that age and tick infestations $(\mathrm{p}<0.05)$ might play an important role in the spread of babesiosis as animal less than 6 months old. A high correlation (Kappa index of 0.70 for B. bovis and 0.65 for $B$. bigemina, respectively) between serological and molecular tests suggests that the combination of the utilized techniques in the present study is suitable for babesiosis diagnosis in an endemic unstable area.
\end{abstract}

Key words: Babesiosis, Brazil, diagnosis, ELISA, PCR

\section{Resumo}

A babesiose bovina é uma importante doença do gado, onde Rhipicephalus microplus atua como um vetor para os dois organismos causais Babesia bovis e Babesia bigemina. Um total de 22 animais foram aleatoriamente e monitorados durante três anos, por nested PCR e teste de ELISA para determinar a prevalência de B. bovis e B. bigemina. A prevalência global de B. bovis e B. babesia foi de $30 \%$ e $35 \%$, em $n \mathrm{PCR}$, e $70 \%$ e $75 \%$ por ELISA, respectivamente. A análise estatística das características dos animais mostrou que a idade e carrapatos $(\mathrm{p}<0,05)$ podem desempenhar um papel importante na propagação de babesiose em animais com menos de 6 meses de idade. Uma correlação elevada (índice Kappa de 0,70 para $B$. bovis e $B$. babesia 0,65 , respectivamente) entre os testes sorológicos e moleculares sugere que a combinação das técnicas utilizadas no presente estudo é adequado para o diagnóstico da babesiose numa área de instabilidade endémica.

Palavras-chave: Babesiose, Brasil, diagnóstico, ELISA, PCR

${ }^{1}$ Discente da Faculdade de Ciências Agrárias e Veterinária, Universidade Estadual Paulista, FCAV/UNESP, Jaboticabal SP, Brasil. E-mail: jenevaldo@hotmail.com

2 Discente da Universidade Federal Rural do Rio de Janeiro, UFRRJ, Seropédica, RJ, Brasil. E-mail: priscillanunes@rocketmail. com

3 Prof., UFRRJ, Seropédica, RJ, Brasil. E-mail: adivaldo@ufrrj.br

* Author for correspondence 


\section{Introduction}

Rhipicephalus microplus is considered the most important vector of pathogens that cause disease in cattle. Rhipicephalus microplus, are distributed in tropical and subtropical regions of the world, where they economically impact cattle industry by reducing weight gain and milk production, and by transmitting pathogens (PETER et al., 2005).

Bovine babesiosis is a tick-borne disease of cattle that is caused by one or more intraerythrocytic protozoa of the genus Babesia, order Piroplasmida, phylum Apicomplexa and is generally characterized by significant morbidity and mortality worldwide (McCOSKER, 1981). Although outbreak reports and localized epidemiological studies have been published in the last decade, comprehensive and detailed descriptions of the epidemiology of bovine piroplasmoses are still lacking in Brazil.

The disease is clinically manifested by anemia, fever, hemoglobinuria, and marked splenomegaly and sometimes causes death. Of the species affecting cattle, Babesia bovis and Babesia bigemina are the most economically important species worldwide. The economic losses from the infection are incurred not only from mortality, loss of milk/meat production, and cost of control measures but also through its impact on the international cattle trade (BOCK et al., 2004).

Definitive diagnosis of babesial infection is generally made by microscopic identification of Giemsa or Wright stained blood smears. This technique is not reliable for detecting the infection in carrier cattle and for differentiating closely related infections (TERKAWI et al., 2011). Molecular detection based on PCR technique has been proven to provide reliable results with high sensitivity and specificity in detection of babesial DNA in blood, particularly when the parasitemia is very low or no detectable in microscopic examination (FIGUEROA et al., 1993). Serological tests, the enzyme-linked immunosorbent assays (ELISA) are capable of detecting the infection in carrier animals and have been broadly used for surveillance and export certification (GOFF et al., 2006; SILVA et al., 2014).

Consequently, combination of molecular and serological test for the infection provides powerful tools for accurate diagnosis as well as for epidemiological investigations (TERKAWI et al., 2011). Thus, we investigated in a longitudinal study the detection of $B$. bovis and B. bigemina by ELISA test and PCR assay in cattle.

\section{Materials and Methods}

\section{Background}

Field activities were conducted from September 2008 to August 2011, at the Dairy Cattle Division of Seropédica Experimental Station, Agricultural Research Corporation of the State of Rio de Janeiro (Pesagro- Rio). The experimental area was located in the microregion of the Metropolitan Region of Rio de Janeiro (latitude $22^{\circ} 45^{\prime} \mathrm{S}$ and longitude $43^{\circ}$ $41^{\prime} \mathrm{W}$ and altitude $33 \mathrm{~m}$ ).

\section{Field blood samples}

By means of proportional stratified sampling, 22 calves were randomly selected. Blood samples were collected every thirty days from birth until the three year of age. The herds are usually moved to pasture during the study. Cattle between 1 and 36 months old were divided into three groups based on their age; young (1 year), old (1-2 years) and older (2-3 years).

Blood was collected from the caudal or jugular vein of individual cattle with EDTA or without, incubated at room temperature for $2 \mathrm{~h}$, and then centrifuged at $3000 \mathrm{rpm}$ for $10 \mathrm{~min}$. The sera were collected and then stored at $-20{ }^{\circ} \mathrm{C}$ until use. The genomic DNA samples were extracted from the whole blood using a commercial kit (QIAamp DNA Blood Mini-Kit, Madison, WI, USA) according to the manufacturer's instructions. 


\section{ELISA}

The assay was then performed as earlier described (Machado et al., 1997). Briefly, $100 \mu 1$ of antigen diluted in $0.05 \mathrm{M}$ carbonate/bicarbonate buffer, $\mathrm{pH}$ 9.6, was added to each well of a microELISA plate (Immulon ${ }^{\circ}$; Dynatech Laboratories Inc.) and protein concentration was adjusted to 10 $\mu \mathrm{g} / \mathrm{m} 1-1$. The plates were sealed and incubated overnight at $4{ }^{\circ} \mathrm{C}$. Plates were blocked for $1 \mathrm{~h}$ at $37{ }^{\circ} \mathrm{C}$ in a humid chamber with $3 \%$ ovalbumin in carbonate/bicarbonate buffer. After five washes with buffer (phosphatebuffered saline, $\mathrm{pH}$ 7.2, and $0.05 \%$ Tween 20, PBS-Tween), $100 \mu 1$ of diluted bovine sera (1:400) in PBS-Tween plus 5\% normal rabbit serum were added in duplicate to the ELISA plate. Plates were incubated at $37{ }^{\circ} \mathrm{C}$ in a humid chamber for 90 min and then washed five times with PBS-Tween. A $100 \mu 1$ aliquot of a 1:10000 dilution of alkaline phosphatase conjugated anti-bovine $\mathrm{IgG}$ (Sigma Chemical Co.) was added to each well and the plates were incubated at $37{ }^{\circ} \mathrm{C}$ under the same conditions for $90 \mathrm{~min}$. Plates were washed five times with PBS-Tween. The appropriate substrate (p-nitrophenyi phosphate) was added and the plates were sealed and incubated for $40 \mathrm{~min}$ at room temperature. The plates were then read at $405 \mathrm{~nm}$ wavelength on a micro-ELISA reader (B.T.-100; Embrabio, São Paulo, Brazil). The cut-off values were calculated based on 10 non- $B$. bovis and $B$. bigemina-infected calves sera.

\section{Nested-PCR}

The reaction was conducted in a $25 \mu 1$ reaction mixture containing $5 \mu 1$ of extracted genomic DNA, $12.5 \mu 1$ of PCR master mix (Roche), and a $1.6 \mu \mathrm{M}$ concentration of eachprimerset.Briefly, oneuniversal forward primer and two unique reverse primers were designed to amplify the $18 \mathrm{~S}$ rRNA gene. The primer sequences are as follows: $B$. bovis primers forward: 5'-AGTTGTTGGAGGAGGCTAAT-3' and reverse: 5'-TCCTTCTCGGCGTCCTTTTC-3' and $B$. bigemina primers forward 5'-
GAGTCTGCCAAATCCTTAC-3' and reverse 5'-TCCTCTACAGCTGCTTCG-3' (TERKAWI et al., 2011). PCR amplifications were performed at 94 ${ }^{\circ} \mathrm{C}$ for 3 min followed by 34 repetitive cycles of 94 ${ }^{\circ} \mathrm{C}$ for $1 \mathrm{~min}, 55^{\circ} \mathrm{C}$ for $1 \mathrm{~min}$, and $72{ }^{\circ} \mathrm{C}$ for $2 \mathrm{~min}$, followed by a final extension at $72{ }^{\circ} \mathrm{C}$ for $7 \mathrm{~min}$. The $n$ PCR conditions were the same as described above, $1 \mu 1$ of the primary PCR product was used as template and amplified with 10 pmol of each of the primer $(B$. bovis forward 5'-GAAATCCCTGTTCCAGAG-3' and reverse 5'-TCGTTGATAACACTGCAA-3' and $B$ bigemina forward 5'-AGCTTGCTTTCACAACTCGCC-3', and reverse 5'-TTGGTGCTTTGACCGACGACAT-3'). PCR products (primary as well as nested) were checked for amplification by electrophoresis on a $2.0 \%$ agarose gel and visualized using gel documentation system (Syngene, UK).

\section{Tick}

To count the ticks, the animals were restrained individually, and all the fully or partially engorged females of $R$. microplus measuring between 4.5 and $8.0 \mathrm{~mm}$ that were found on the right side of each animal were counted as described by Wharton, Utech and Turner (1970). The result from each count was multiplied by 2 to obtain the monthly average for each animal. The chi-square test was used to evaluate significant differences $(\mathrm{P}<0.05)$ of infection rate in animals by $B$. bovis and $B$. bigemina. The kappa coefficient was calculated to evaluate the agreement among the $n$ PCR assay and ELISA test. The operational procedures were done using the R statistical software ( $\mathrm{R}$ Foundation for Statistical Computing, version 2.12.2, 2011).

\section{Results and Discussion}

The fluctuation of the prevalence of $B$. bovis and $B$. bigemina was compared on the basis in animals of different months old (Figure 1). Analysis of serological data for $B$. bovis revealed a prevalence of $51,60 \%$ and $70 \%$ among animals of age $\geq 1$ to 
$\leq 12$ months, $>12$ to $\leq 24$ and over 24 months, respectively. For $B$. bigemina the seroprevalence was $50 \%, 68 \%$ and $76 \%$ for the three age groups examined. In a study on dairy cattle, Tembue et al. (2011) observed that animal less than 1 year old and those having ticks present on them were more infected with B. bovis and B. bigemina.

Figure 1. Serological detection of Babesia bovis and Babesia bigemina in cattle from Rio de Janeiro, Brazil. Twenty two calves were evaluated by ELISA every three months during the three year of life.

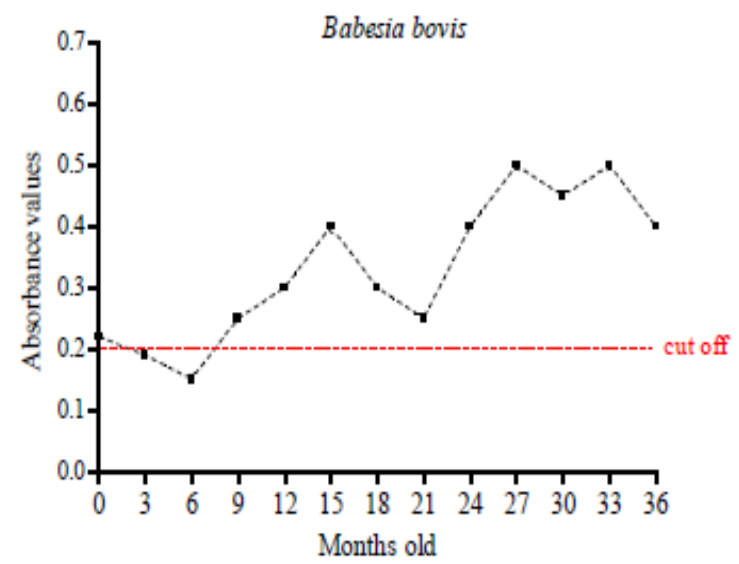

Babesia bovis

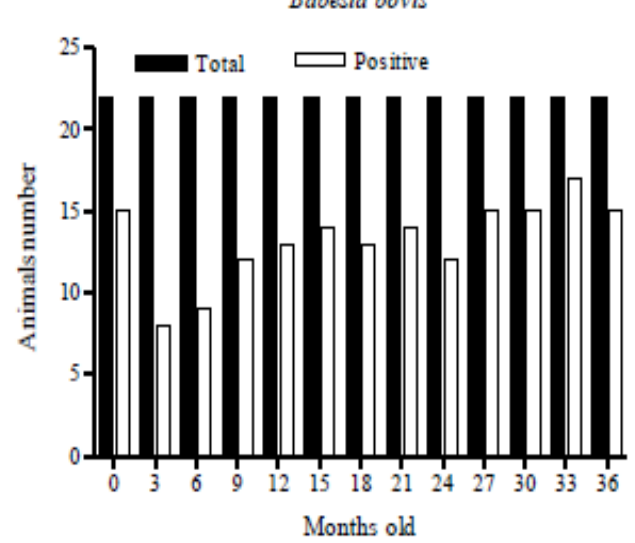

Source: Elaboration of the authors.

Statistically significant differences $(\mathrm{P}<0.05)$ were essentially observed in aged cattle for both parasitic infections for both agents (Figure 2). This was consistent with related studies that noted an increase in the prevalence in older cattle (APPLEWHAITE; CRAIG; WAGNER, 1981;
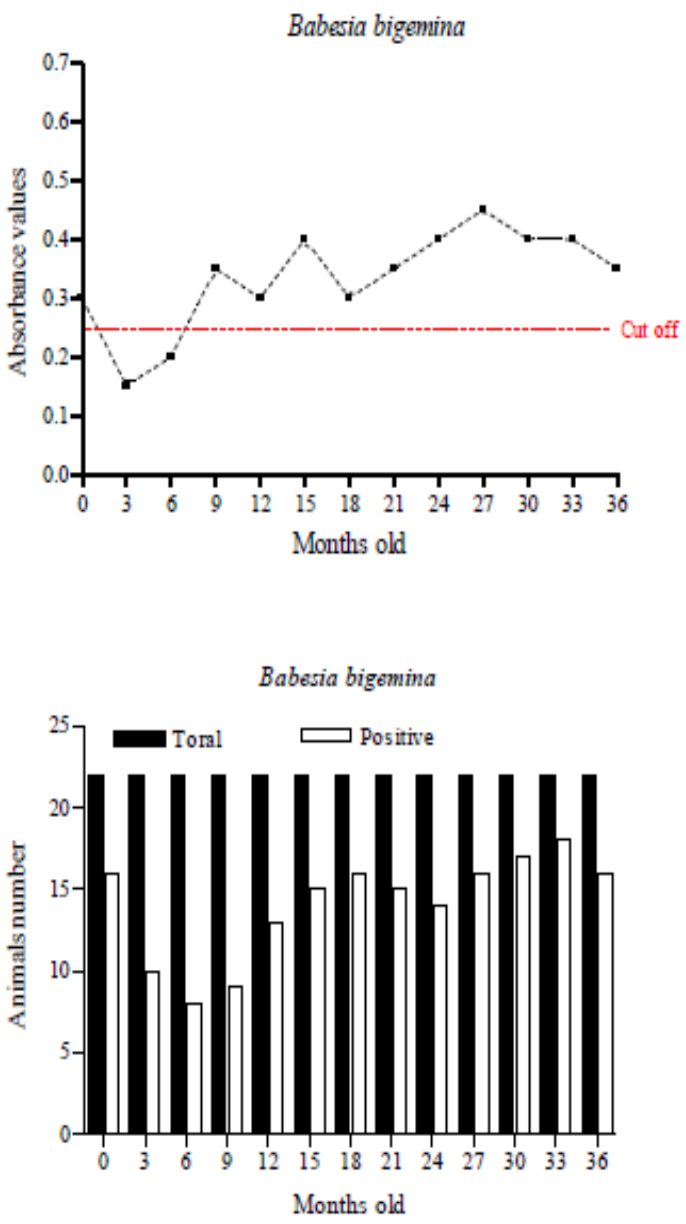

SUKANTO; PAYNE; PARTOUTOMO, 1993). In general, young and adults are susceptible to babesiosis, while calves are naturally resistant due to the strong innate immune response with high concentration of nitric oxide in the spleen (ZINTL et al., 2005). 
Figure 2. Comparisons of the prevalence serological (ELISA) and molecular (nPCR) of Babesia bovis and Babesia bigemina infections on the basis of age of calves in state of Rio de Janeiro, Brazil. Each asterisk indicates a significant difference $(* \mathrm{p}<0.05)$.

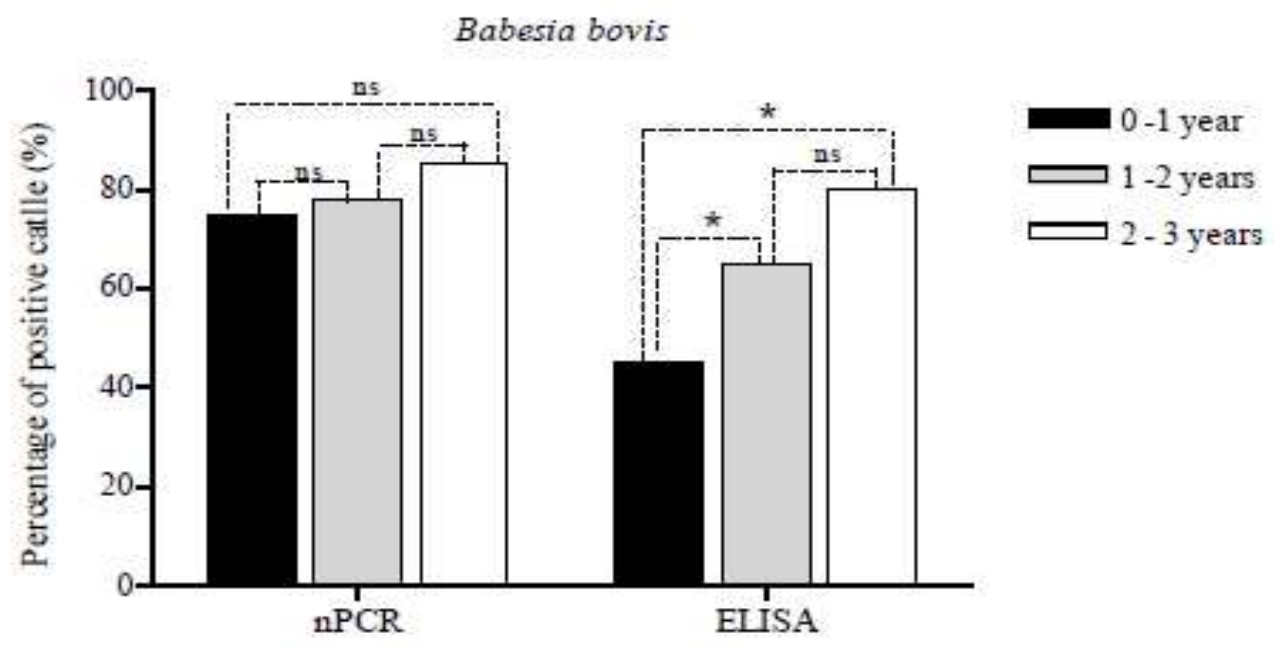

Babesia bigemina
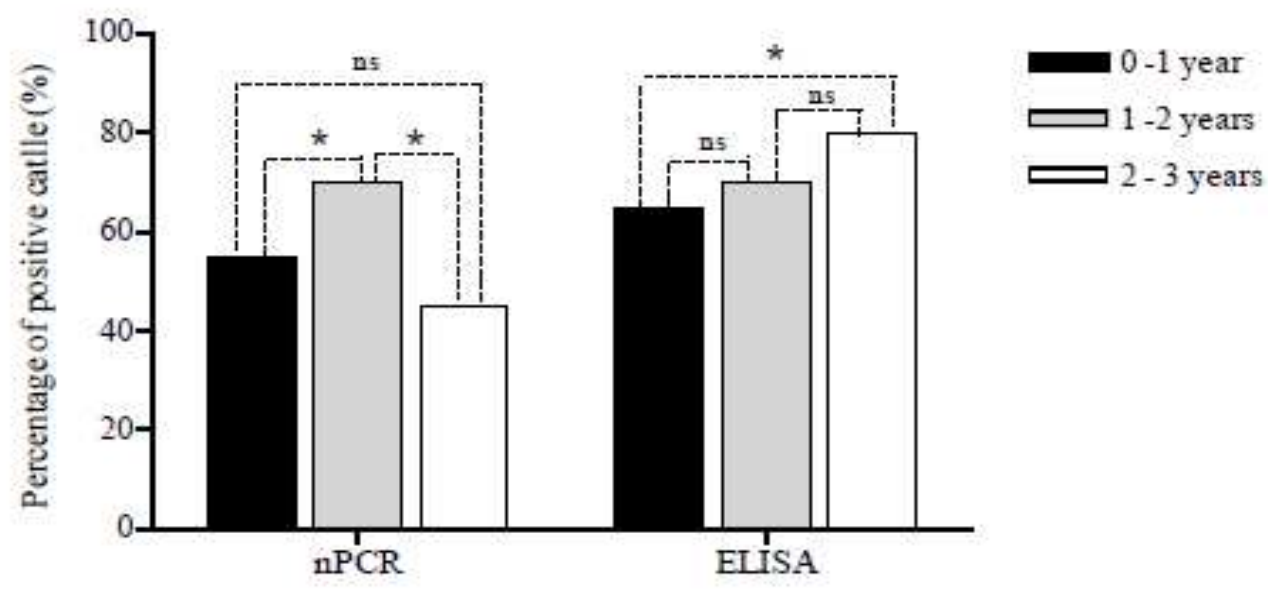

Source: Elaboration of the authors.

In this study the tick infestation showed to be an important risk factor for babesiosis (Figure 3). Regarding animal age, the results from the present study are agree with what was observed by Andrade et al. (1998), who noticed a linear increase in the number of ticks as the animals became older. Conversely, highly specialized susceptible cattle from low endemicity areas are subject to great risk when introduced to high endemicity or places where tick populations fluctuate during the year (JONSSON; BOCK; JORGENSEN, 2008). It is possible that in the studied herds in a low vector population by insufficient for maintaining constant transmission of B. bovis and B. bigemina. In this case, an imbalance caused by the parasite-host relationship due to infrequent transmission creates an artificial endemic instability condition. 
Figure 3. Comparisons of the prevalence molecular (nPCR) of Babesia bovis and Babesia bigemina with Rhipicephalus microplus count in cattle of Rio de Janeiro, Brazil.

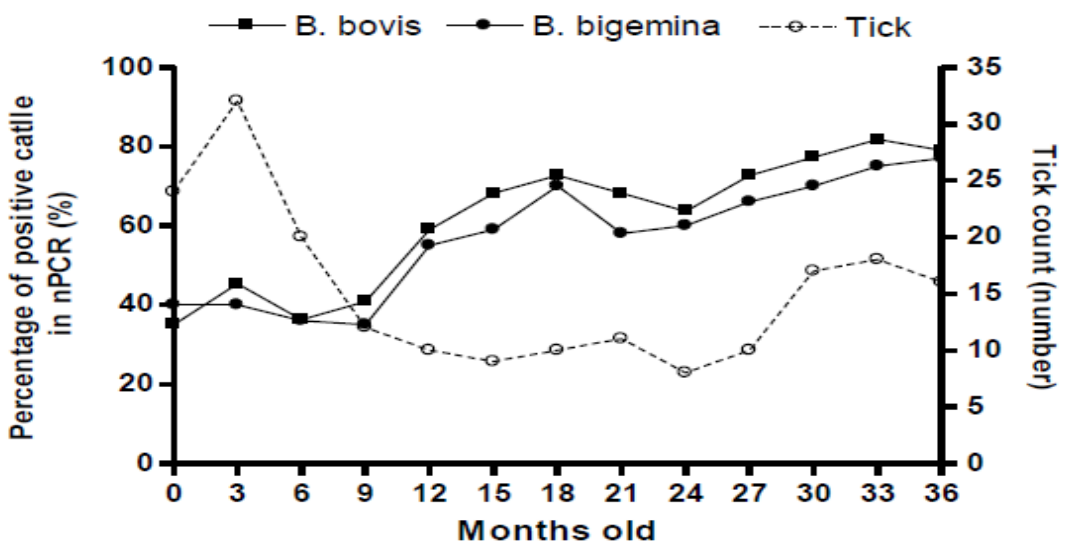

Source: Elaboration of the authors.

Although this serological assay detected higher positive rates of both parasites than the molecular detection method, the results obtained from the $n$ PCR assay were highly concordant with this of ELISA, as determined by the kappa values, which were calculated to be 0.65 and 0.70 for $B$. bovis and $B$. bigemina, respectively (Figure 4 ). While these findings are similar to that found by Terkawi et al. (2011). In a nutshell, our results showed that a combination of both molecular and serological techniques is useful tool in for epidemiological investigations with high accuracy in the diagnosis of Babesia sp. in cattle.

The present work showed that water cattle from state of Rio de Janeiro, Brazil, are exposed to bovine babesiosis agents, although do not show clinical signs of the disease. The PCR and ELISA diagnosis of $B$. bovis and B. bigemina utilizing blood as a source to obtain template DNA proved efficient in detecting hemoparasites in asymptomatic cattle bred in the regions studied.

Figure 4. Molecular and serological detection of B. bovis and B. bigemina using $n \mathrm{PCR}$ assay and ELISA test. The results of $n \mathrm{PCR}$ were cross-tabulated with these of ELISA. Twenty two calves were evaluated by ELISA every three months during the three year of life.

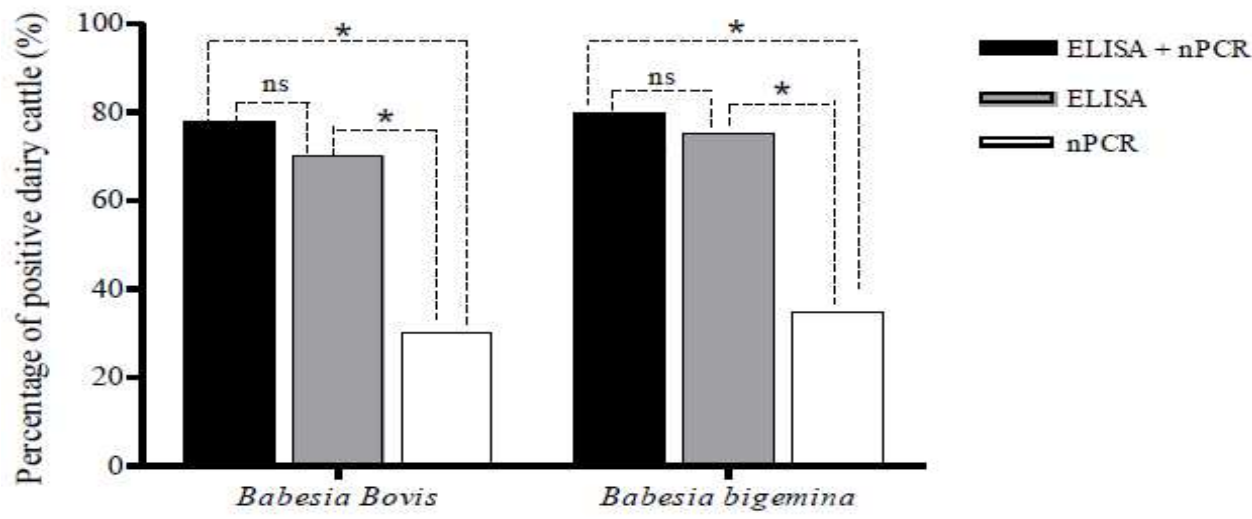

Source: Elaboration of the authors. 


\section{Acknowledgements}

We are grateful to Dra. Rosangela Zacarias Machado by kindly supplied the antigen used. We also thank the Coordination for the Improvement of Higher Level of Education Personnel (CAPES) for financial support.

\section{References}

ANDRADE, A. B. F.; SILVA, R. G.; COSTA, A. J.; ROCHA, U. F.; LANDIM, V. J. C. Genetic and environmental aspects of the resistance of Zebu cattle to the tick Boophilus microplus. In: WORLD CONGRESS ON GENETICS APPLIED TO LIVESTOCK PRODUCTION, 6, 1998, Armidale. Proceedings... Armidale: NSW, 1998. p. 339-342.

APPLEWHAITE, L. M.; CRAIG, T. M.; WAGNER, G. G. Serological prevalence of bovine babesiosis in Guyana. Tropical Animal Health and Production, Edinburgh, v. 13, n. 1, p. 13-18, feb. 1981.

BOCK, R.; JACKSON, L.; de VOS, A.; JORGENSEN, W. Babesiosis of cattle. Parasitology, Cambridge, v. 129, n. 1, p. 247-269, 2004.

FIGUEROA, J. V.; CHIEVES, L. P.; JOHNSON, G. S.; BUENING, G. M. Multiplex polymerase chain reaction based assay for the detection of Babesia bigemina, Babesia bovis and Anaplasma marginale DNA in bovine blood. Veterinary Parasitology, Amsterdam, v. 50, n. 1, p. 69-81, oct. 1993.

GOFF, W. L.; JOHNSON, W. C.; MOLLOY, J. B.; JORGENSEN, W. K.; WALDRON, S. J.; FIGUEROA, J. V.; MATTHEE, O.; ADAMS, D. S.; MCGUIRE, T. C.; PINO, I.; MOSQUEDA, J.; PALMER, G. H.; SUAREZ, C. E.; KNOWLES, D. P.; MCELWAIN, T. F. Validation of a competitive enzyme-linked immunosorbent assay for detection of antibodies against Babesia bovis. Clinical and Vaccine Immunology, Washington, v. 13, n. 1, p. 1212-1216, 2006.

JONSSON, N. N.; BOCK, R. E.; JORGENSEN, W. K. Productivity and health effects of anaplasmosis and babesiosis on Bos indicus cattle and their crosses, and the effects of differing intensity of tick control in Australia. Veterinary Parasitology, Amsterdam, v. 155, n. 1, p. 1-9, aug. 2008.
MACHADO, R. Z.; MONTASSIER, H. J.; PINTO, A. A.; LEMOS, E. G.; MACHADO, M. R. F.; VALADÃO, I. F. F.; BARCI, L. G.; MALHEIROS, E. B. An enzymelinked immunosorbent assay (ELISA) for the detection on antibodies against Babesia bovis in cattle. Veterinary Parasitology, Amsterdam, v. 71, n. 1, p. 17-26, jul. 1997.

McCOSKER, P. J. The global importance of babesiosis. In: RISTIC, M.; KRIER, J. P. (Ed.). Babesiosis. New York: Academic Press, 1981. n. 1, p. 1-24.

PETER, R. J.; VAN DEN BOSSCHE. P.; PENZHORN. B. L.; SHARP, B. Tick, fly, and mosquito controllessons from the past, solutions for the future. Veterinary Parasitology, Amsterdam, v. 132, n. 3, p. 205-15, sept. 2005.

SILVA, J. B.; CORDEIRO, M. D.; CASTRO, G. N. S.; SANTOS, P. N.; FONSECA, A. H.; REIS, A. B.; SILVA, N. S.; BARBOSA, J. D. Ocorrência sorológica de Babesia bovis, Babesia bigemina e Anaplasma marginale em bovinos e Bubalinos no estado do Pará, Brasil. Semina: Ciências Agrárias, Londrina, v. 35, n. 5, 2014.

SUKANTO, I. P.; PAYNE, R. C.; PARTOUTOMO, S. Bovine babesiosis in Indonesia. Preventive Veterinary Medicine, Colorado, v. 16, n. 1, p. 151-156, jul. 1993.

TEMBUE, A. A. M.; SILVA. F. J. M.; SILVA, J. B.; SANTOS, T. M.; SANTOS, H. A.; SOARES, C. O.; FONSECA, A. F. S. Risk factors associated with the frequency of antibodies against Babesia bovis and Babesia bigemina in cattle in southern Mozambique. Pesquisa Veterinária Brasileira, Seropédica, v. 31, n. 8 , p. 663-666, aug. 2011.

TERKAWI, M. A.; HUYEN, N. X.; SHINUO, C.; INPANKAEW, T.; MAKLON, K.; ABOULAILA, M.; UENO, A.; GOO, Y. K.; YOKOYAMA, N.; JITTAPALAPONG, S.; XUAN, X.; IGARASHI, I. Molecular and serological prevalence of Babesia bovis and Babesia bigemina in water buffaloes in the northeast region of Thailand. Veterinary Parasitology, Amsterdam, v. 178, n. 3, p. 201-207, jun. 2011.

WHARTON, R. H.; UTECH, K. B. W.; TURNER, H. G. Resistance to cattle tick, Boophilus microplus in a herd of Australian Illawarra Shorthorn Cattle - its assessment and heritability. Australian Journal of Agricultural Research, Oxford, v. 21, n. 1, 163-180, 1970.

ZINTL,A.; GRAY, J. S.; SKERRETT, H. E.; MULCAHY, G. Possible mechanisms underlying age-related resistance to bovine babesiosis. Parasite Immunology, Oxford, v. 27, n. 4, p. 115-120, apr. 2005. 
